\title{
Alterations in tumour suppressor gene p53 in human gliomas from Indian patients
}

\author{
Pornima Phatak, S Kalai Selvi, T Divya*, A S Hegde*, SRidevi Hegde* and \\ KUMARAVEL SOMASUNDARAM ${ }^{\dagger}$ \\ Department of Microbiology and Cell Biology, Indian Institute of Science, Bangalore 560 012, India \\ *Manipal Institute for Neurological Disorders, Manipal Hospital, Airport Road, Bangalore 560 017, India \\ ${ }^{\dagger}$ Corresponding author (Fax, 91-80-3602697; Email, skumar@mcbl.iisc.ernet.in)
}

\begin{abstract}
Alterations in the tumour suppressor $p 53$ gene are among the most common defects seen in a variety of human cancers. In order to study the significance of the $p 53$ gene in the genesis and development of human glioma from Indian patients, we checked 44 untreated primary gliomas for mutations in exons 5-9 of the $p 53$ gene by PCR-SSCP and DNA sequencing. Sequencing analysis revealed six missense mutations. The incidence of p53 mutations was $13.6 \%$ ( 6 of 44 ). All the six mutations were found to be located in the central core domain of p53, which carries the sequence-specific DNA-binding domain. These results suggest a rather low incidence but a definite involvement of p53 mutations in the gliomas of Indian patients.
\end{abstract}

[Phatak P, Selvi S K, Divya T, Hegde A S, Hegde S and Somasundaram K 2002 Alterations in tumour suppressor gene p53 in human gliomas from Indian patients; J. Biosci. 27 673-678]

\section{Introduction}

Glioma, a neoplasm of neuroglial cells, is the most common type of brain tumour, constituting more than $50 \%$ of all brain tumours. Gliomas account for about $2 \%$ of the malignant tumours in adults. Malignant gliomas are the leading cause of central nervous system (CNS) tumourrelated death. Patients with glioblastoma have a life expectancy of less than one year even after surgery, chemo- and radiotherapy (Burger and Scheithauer 1993). The prognosis is even worse in children with brain stem malignant gliomas, the death occurring within 6-12 months after diagnosis (Epstein and McCleary 1986). A better understanding of the biological pathway leading to glial tumourigenesis is essential to arrive at new therapeutic modalities.

The $p 53$ tumour suppressor gene is the most frequently altered gene in human cancer, including brain tumours. The p53 protein is a transcription factor involved in maintaining genomic integrity by controlling cell cycle progression and cell survival (Levine 1997; Somasundaram and El-Deiry 2000). Consistent with this view, about $50 \%$ of primary human tumours carry mutations in the p53 gene (Hollstein et al 1991; Levine et al 1991). The function of p53 is critical to the efficiency of many cancer treatment procedures, because radiotherapy and chemotherapy act in part by triggering programmed cell death in response to DNA damage. Consequently, tumours which carry mutations in p53 are often difficult to treat, and their prognosis is poor. The characterization of the biochemical pathways by which p53 alteration triggers tumourigenesis is the foundation for the design of novel therapeutic approaches.

Karyotype analysis and restriction fragment length polymorphism (RFLP) analysis of glioma have shown several numerical and structural alterations of chromosomes (Bigner et al 1988; Libermann et al 1985; James et al 1988; Fujimoto et al 1989). One of the alterations frequently seen in glioma is $\mathrm{LOH}$ on chromosome $17 \mathrm{p}$, which leads to deletion of the region that includes p53 (Chung et al 1991; Frankel et al 1992; Fults et al 1992; von Deimling et al 1992; Ghosh et al 1994; Rasheed et al

Keywords. Gliomas; mutations; p53; single strand conformation polymorphism. 
1994; Jain et al 1999). Studies at many laboratories have shown that approximately $25 \%$ of the glioma carries mutations in p53 gene (Nigro et al 1989; Chung et al 1991; Mashiyama et al 1991; Ohgaki et al 1991; Frankel et al 1992; Fults et al 1992; Saxena et al 1992; von Deimling et al 1992; Louis et al 1993).

In the study reported here, we tested 44 glioma samples from Indian patients for mutations in the p53 tumour suppressor gene by PCR-SSCP method. We found the p53 gene mutated in $13.6 \%(6 / 44)$ of the gliomas.

\section{Materials and methods}

\subsection{Tumour samples}

Glioma tissue samples were obtained from patients who underwent surgery at Manipal Hospital, Bangalore, India. Forty-four patients with different grades of glioma were chosen for the study. Tissue samples were kept frozen at $-70^{\circ} \mathrm{C}$. Total DNA was isolated from a part of the frozen samples. Tissue sections were used to identify the histopathological grade and the type of glioma.

\subsection{Isolation of DNA}

A commercial DNA isolation kit (Qiagen, USA) was used to isolate genomic DNA from $25 \mathrm{mg}$ of glioma tissue.

\subsection{Primers for PCR and DNA sequencing}

The primers used were oligonucleotides complementary to the sequence flanking the exon/intron junctions of exons 5-9 (Kovach et al 1991). The sequence of the primers is as follows: exon 5, 5'-CTGACTTTCAACTCTG-3' (forward) and 5'-AGCCCTGTCGTCTCT-3' (reverse); exon 6, 5'CTCTGATTCCTCACTG-3' (forward) and 5'-ACCCCA GTTGCAAACC-3' (reverse); exon 7, 5'-TGCTTGCCACA GGTCT-3' (forward) and 5'-ACAGCAGGCCAGTGT-3' (reverse); exon 8, 5'-AGGACCTGATTTCCTTAC-3' (forward) and 5'-TCTGAGGCATAACTGC-3' (reverse); exon 9, 5'-TATGCCTCAGATTCACT-3' (forward) and 5'-ACTTGATAAGAGGTCC-3' (reverse). The same sets of primers were used for DNA sequencing.

\subsection{Polymerase chain reaction}

Genomic DNA (100 ng) was used for amplification in $25 \mu$ of reaction mixture. The composition of the $10 \mathrm{X}$ buffer used for all exons (except exon 7) was: $100 \mathrm{mM}$ Tris- $\mathrm{HCl}$ ( $\mathrm{pH} 9.0$ ), $15 \mathrm{mM} \mathrm{MgCl}_{2}, 500 \mathrm{mM} \mathrm{KCl}, 0.1 \%$ gelatin. For exon 7, the composition was: $100 \mathrm{mM}$ Tris$\mathrm{HCl}(\mathrm{pH} \mathrm{8.3)}, 35 \mathrm{mM} \mathrm{MgCl} 2,250 \mathrm{mM} \mathrm{KCl}$. Each PCR reaction had a 1X PCR buffer, $100 \mu \mathrm{M}$ dNTPs (Gibco BRL), $5 \mu \mathrm{Ci} \alpha\left[{ }^{32} \mathrm{P}\right] \mathrm{dATP}, 5 \mathrm{pmol}$ of each primer (Microsynth) and $0.5 \mathrm{U}$ of Taq DNA polymerase (Bangalore Genei). PCR conditions for exon 5,6 and 8 were $94^{\circ} \mathrm{C}$ for $5 \mathrm{~min}, 30$ cycles of $94^{\circ} \mathrm{C}$ for $1 \mathrm{~min}, 57^{\circ} \mathrm{C}$ for $1 \mathrm{~min}$ and $72^{\circ} \mathrm{C}$ for $30 \mathrm{~s}$ and a final cycle of $72^{\circ} \mathrm{C}$ for $10 \mathrm{~min}$. The condition for exon 7 was $94^{\circ} \mathrm{C}$ for $5 \mathrm{~min}, 30$ cycles of $94^{\circ} \mathrm{C}$ for $1 \mathrm{~min}, 65^{\circ} \mathrm{C}$ for $1 \mathrm{~min}$ and $72^{\circ} \mathrm{C}$ for $10 \mathrm{~s}$, and a final cycle of $72^{\circ} \mathrm{C}$ for $10 \mathrm{~min}$. The condition for exon 9 was $94^{\circ} \mathrm{C}$ for $5 \mathrm{~min}, 30$ cycles of $94^{\circ} \mathrm{C}$ for $1 \mathrm{~min}, 56^{\circ} \mathrm{C}$ for $1 \mathrm{~min}$ and $72^{\circ} \mathrm{C}$ for $15 \mathrm{~s}$, and a final cycle of $72^{\circ} \mathrm{C}$ for $10 \mathrm{~min}$.

\subsection{Single strand conformation polymorphism analysis}

Labelled PCR products were checked for amplification by $2 \%$ agarose gel electrophoresis, diluted to 10 to 100 fold in a loading and denaturing buffer $(95 \%$ formamide, $0.25 \%$ bromophenol blue, 0.25 xylene cyanol, $10 \mathrm{mM}$ EDTA, pH 8.0 and $0.1 \mathrm{~N} \mathrm{NaOH}$ ), heated at $85^{\circ} \mathrm{C}$ for 5 min and then subjected to single strand conformation polymorphism (SSCP) analysis using 6\% non-denaturing polyacrylamide gel with $5 \%$ glycerol and $0 \cdot 5 \mathrm{X}$ TBE as running buffer. Electrophoresis was carried out at $500 \mathrm{~V}$ for $3.5 \mathrm{~h}$ at $22^{\circ} \mathrm{C}$ for exons $5,6,7$ and 9 . For exon 8 , the conditions remained the same, except that the gel was run at $15^{\circ} \mathrm{C}$. Samples that showed band shifts were chosen for further study.

\subsection{Direct DNA sequencing}

Bands showing abnormal shifts in the SSCP analysis were purified from acrylamide gel using Microcon spin columns (Millipore) and used as templates to reamplify the fragment with the same set of primers originally used for amplification. The amplified DNA fragments were purified with a QIAquick PCR purification kit (Qiagen) and subjected to cycle sequencing (fmol cycle sequencing kit; Promega) in both directions. Sequencing reactions were carried out in a thermal cycler under the following cycling conditions: $95^{\circ} \mathrm{C}$ for $2 \mathrm{~min}, 30$ cycles of $95^{\circ} \mathrm{C}$ for $30 \mathrm{~s}, 42^{\circ} \mathrm{C}$ for $30 \mathrm{~s}$, and $70^{\circ} \mathrm{C}$ for $1 \mathrm{~min}$. The samples were electrophoresed on a $6 \%$ polyacrylamide denaturing gel. Gels were dried under vacuum at $80^{\circ} \mathrm{C}$, and exposed for Phosphor Imaging.

\section{Results}

\subsection{PCR-SSCP analysis for detection of mutations}

PCR fragments generated from exons 5 to 9 of the p53 gene were subjected to SSCP analysis. All 44 glioma 
samples were checked for mutations. DNA samples showing mobility shifts or abnormal bands were scored as positive for mutation. Of the 44 samples analysed, six tumour DNAs showed an altered pattern in PCR-SSCP analysis (figure 1; table 1). Exon 5 analysis revealed the presence of mutation in samples G2 (figure 1a), G10 (data not shown) and G20 (figure 1b). Sample 34 showed a differentially migrating band in exon 7 (figure 1c). Samples G23 and G33 (figure 1d) showed additional bands in exon 8 moving differently from normal bands.

\subsection{Identification of mutations by sequence analysis}

The bands that showed abnormal shifts in all the samples mentioned above were purified from gel and subjected to DNA sequencing. The sequencing revealed the presence of mutation in all the six samples. Figure 2 shows the results of sequencing of some of the samples. Exon 5 of samples $\mathrm{G} 2$ and $\mathrm{G} 10$ had the same missense mutation (G-T), resulting in the conversion of valine to phenylalanine at codon 172 (figure 2a). Exon 5 of sample G20 had the missense mutation $(T-G)$, resulting in the conversion of valine to glycine at codon 173 (data not shown). Exon 7 of sample G34 showed the missense mutation ( $\mathrm{T}-\mathrm{G})$, which converted leucine to arginine at codon 257 (data not shown). Exon 8 of G23 had the missense mutation $(\mathrm{C}-\mathrm{T})$, which caused the conversion of arginine to cysteine at codon 273 (figure 2b). G33 had the missense mutation $(T-G)$ in exon 8 , which resulted in the conversion of phenylalanine to cysteine at codon 270 (figure 2c).

\section{Discussion}

The most frequent chromosomal abnormalities associated with glioma are gains of chromosome 7 , losses of $10,9 p$ and $17 \mathrm{p}$ and EGFR gene amplification (Libermann et al 1985; Bigner et al 1988; James et al 1988; Fujimoto et al 1989). The loss of $17 \mathrm{p}$ is usually associated with mutations in the p53 gene (Chung et al 1991; Frankel et al 1992; Fults et al 1992; von Deimling et al 1992; Ghosh et al 1994; Jain et al 1999). The involvement of p53 in the development of glioma from Indian patients has been shown by loss of heterozygosity (LOH) analysis (Chattopadhyay et al 1997; Gosh et al 1994). The present study was carried out to determine the frequency of p53 mutation in glioma derived from the Indian population. We analysed 44 glioma samples to check for mutations in (a)

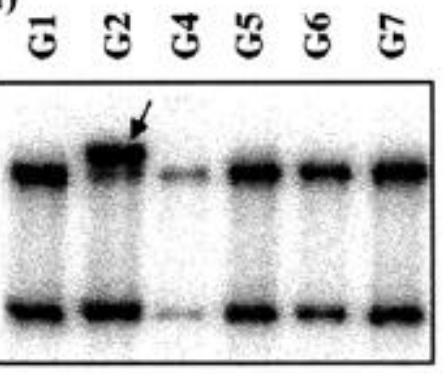

(b)

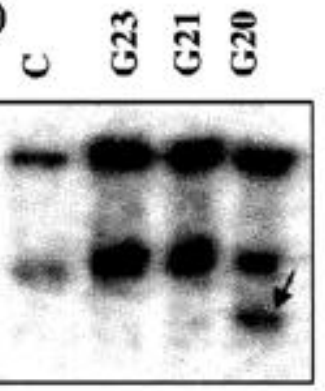

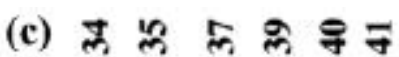
ט

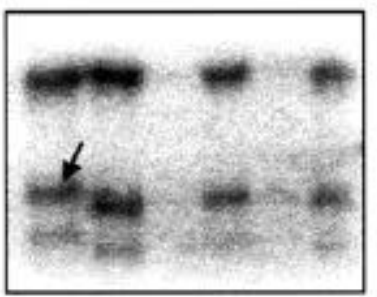

(d)

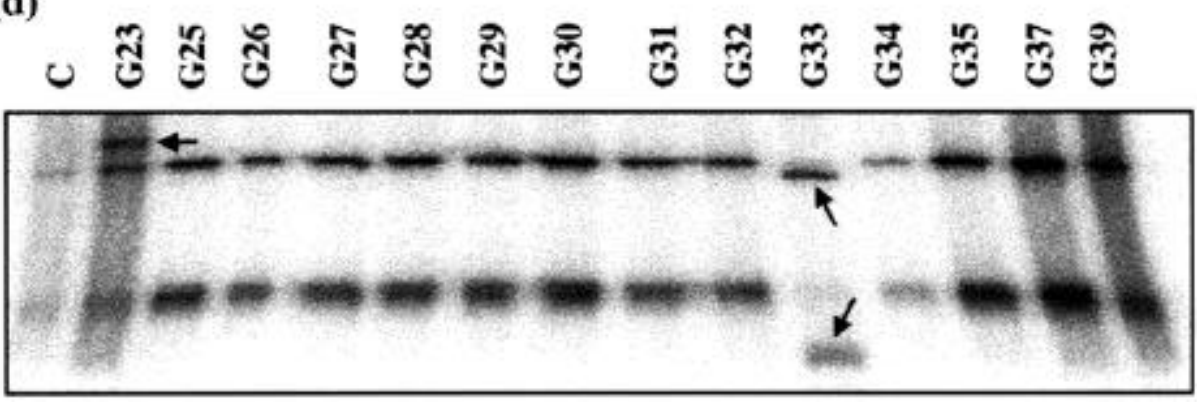

Figure 1. PCR-SSCP analysis of glioma samples. The exons 5, 6, 7, 8 and 9 of p53 gene were amplified in the presence of $\alpha\left[{ }^{32}\right.$ p]dATP using the total genomic DNA as template. The radiolabelled PCR products of exon 5 (a and b), exon 7 (c) and exon 8 (d) were run on a SSCP gel and autoradiographed. Only representative gels showing abnormal bands in comparison to bands in the control lanes are shown. Arrows show the abnormal bands in exon 5 of sample G2 (a), G10 (not shown), G20 (b); exon 7 of sample G34 (c); exon 8 of sample G23 (d) and G33 (d). 
exons 5-9 of p53 gene by the PCR-SSCP method. We found that $13.6 \%$ of the tumours tested positive for $\mathrm{p} 53$ mutations (table 1). To our knowledge, ours is the first study of p53 mutation in glioma from the Indian population.

The central core of $\mathrm{p} 53$, which spans from amino acids 100 to 300 , contains the sequence-specific DNA-binding domain. This is the domain where majority of p53 mutations have been found to occur. In our study, all six mutations were mapped to this domain.
The occurrence of p53 mutations in glioma has generally been associated with age. While the p53 alterations are rare among pediatric age groups, their incidence is high in young adults, and low among the older age group (Louis et al 1993; Rasheed et al 1994). This study shows that the incidence of p53 mutations amongst young adults (19-50 years) is $18 \%(5 / 27)$ and amongst patients $>50$ years old is $6.7 \%(1 / 15)$. No mutations of the $p 53$ gene among the pediatric age group could be detected $(0 / 2)$.

Table 1. Details of glioma samples.

\begin{tabular}{|c|c|c|c|c|c|c|c|c|}
\hline Sample & $\begin{array}{l}\text { Mutated } \\
\text { exon }\end{array}$ & Domain* & Codon & Base & Amino acid & Age/sex & $\begin{array}{l}\text { Histopathological } \\
\text { grade }\end{array}$ & Type** \\
\hline G 1 & - & - & - & & & $46 / \mathrm{M}$ & III & Anaplastic astrocytoma \\
\hline G 2 & 5 & DBD & 172 & $\mathrm{G}$ to $\mathrm{T}$ & Valine to $\mathrm{Ph}$. alanine & $32 / \mathrm{M}$ & III & Anaplastic astrocytoma \\
\hline G 3 & - & - & - & & & $40 / \mathrm{F}$ & III & Anaplastic astrocytoma \\
\hline G 4 & - & - & - & & & 48/M & IV & GBM \\
\hline G 5 & - & - & - & & & $53 / \mathrm{M}$ & II & Astrocytoma \\
\hline G 6 & - & - & - & & & $38 / \mathrm{M}$ & II & Oligoastrocytoma \\
\hline G 7 & - & - & - & & & $59 / \mathrm{M}$ & IV & GBM \\
\hline G 8 & - & - & - & & & $70 / \mathrm{M}$ & IV & GBM \\
\hline G 9 & - & - & - & & & $12 / \mathrm{F}$ & II & Pilocytic astrocytoma \\
\hline G 10 & 5 & DBD & 172 & $\mathrm{G}$ to $\mathrm{T}$ & Valine to $\mathrm{Ph}$. alanine & $68 / \mathrm{F}$ & IV & GBM \\
\hline G 13 & - & - & - & & & $38 / \mathrm{F}$ & III & Anaplastic astrocytoma \\
\hline G 15 & - & - & - & & & $22 / \mathrm{M}$ & III & Anaplastic astrocytoma \\
\hline G 17 & - & - & - & & & $68 / \mathrm{M}$ & IV & GBM \\
\hline G 18 & - & - & - & & & $21 / \mathrm{F}$ & IV & GBM \\
\hline G 19 & - & - & - & & & $36 / \mathrm{M}$ & III & Anaplastic astrocytoma \\
\hline G 20 & 5 & DBD & 173 & $\mathrm{~T}$ to $\mathrm{G}$ & Valine to glycine & $43 / \mathrm{M}$ & III & Anaplastic oligoastrocytoma \\
\hline G 21 & - & - & - & & & $46 / \mathrm{F}$ & II & Astrocytoma \\
\hline G 23 & 8 & DBD & 273 & $\mathrm{C}$ to $\mathrm{T}$ & Arginine to cysteine & $30 / \mathrm{M}$ & II & Astrocytoma \\
\hline G 24 & - & - & - & & & $27 / \mathrm{M}$ & II & Astrocytoma \\
\hline G 25 & - & - & - & & & $58 / \mathrm{F}$ & III & Anaplastic astrocytoma \\
\hline G 26 & - & - & - & & & $68 / \mathrm{F}$ & IV & GBM \\
\hline G 28 & - & - & - & & & $25 / \mathrm{F}$ & III & Oligodendroastrocytoma \\
\hline G 29 & - & - & - & & & 22/M & III & Anaplastic astrocytoma \\
\hline G 30 & - & - & - & & & 49/M & IV & GBM \\
\hline G 31 & - & - & - & & & $14 / \mathrm{M}$ & II & Astrocytoma \\
\hline G 32 & - & - & - & & & $27 / M$ & II & Astrocytoma \\
\hline G 33 & 8 & DBD & 270 & $\mathrm{~T}$ to $\mathrm{G}$ & $\mathrm{Ph}$. alanine to cysteine & 25/M & II & Astrocytoma \\
\hline G 34 & 7 & DBD & 257 & $\mathrm{~T}$ to $\mathrm{G}$ & Leucine to arginine & $37 / \mathrm{M}$ & II & Astrocytoma \\
\hline G 35 & - & - & - & & & $28 / \mathrm{M}$ & IV & GBM \\
\hline G 37 & - & - & - & & & $64 / \mathrm{M}$ & IV & GBM \\
\hline G 39 & - & - & - & & & $35 / \mathrm{M}$ & IV & Gemistocytic astrocytoma \\
\hline G 40 & - & - & - & & & $52 / \mathrm{F}$ & IV & GBM \\
\hline G 41 & - & - & - & & & $50 / \mathrm{F}$ & IV & GBM \\
\hline G 42 & - & - & - & & & $44 / \mathrm{M}$ & IV & GBM \\
\hline G 43 & - & - & - & & & $41 / \mathrm{M}$ & III & Anaplastic astrocytoma \\
\hline G 44 & - & - & - & & & $52 / \mathrm{M}$ & IV & GBM \\
\hline G 45 & - & - & - & & & $35 / \mathrm{M}$ & II & Astrocytoma \\
\hline G 47 & - & - & - & & & $52 / \mathrm{M}$ & IV & GBM \\
\hline G 48 & - & - & - & & & $54 / \mathrm{M}$ & IV & GBM \\
\hline G 49 & - & - & - & & & $21 / \mathrm{M}$ & IV & GBM \\
\hline G 50 & - & - & - & & & $63 / \mathrm{M}$ & II & Pilocytic astrocytoma \\
\hline G 52 & - & - & - & & & $68 / \mathrm{M}$ & III & Anaplastic astrocytoma \\
\hline G 53 & - & - & - & & & $55 / \mathrm{M}$ & III & Anaplastic astrocytoma \\
\hline G 54 & - & - & - & & & $42 / \mathrm{F}$ & IV & GBM \\
\hline
\end{tabular}

*DBD refers to DNA binding domain of p53; **GBM refers to glioblastoma multiforme. 
About $83 \%$ of the mutations were found in young adults $(5 / 6)$, while only $17 \%$ were found in the older group (1/6). Thus our results confirm the relationship between p53 mutation and the age of the patient, as shown pre-
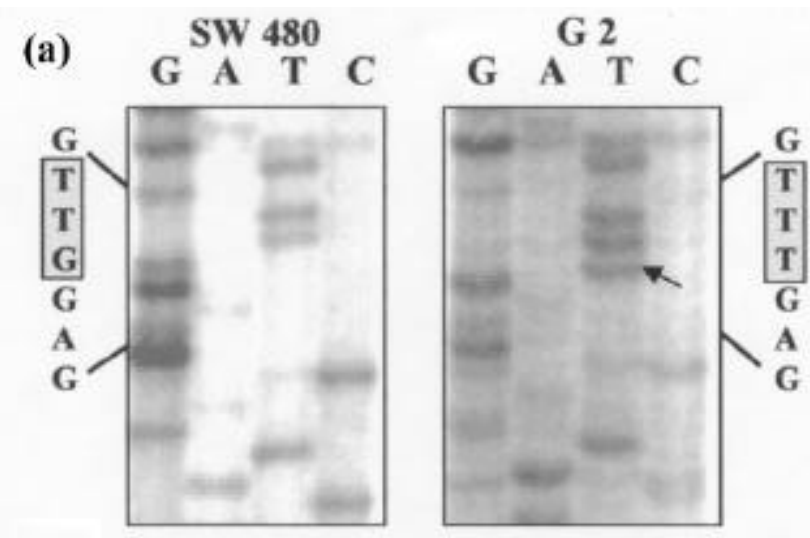

(b)

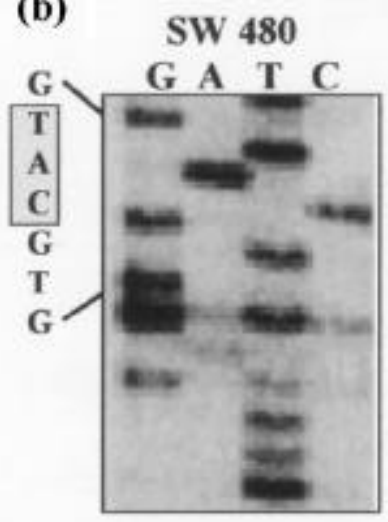

\section{G 23}

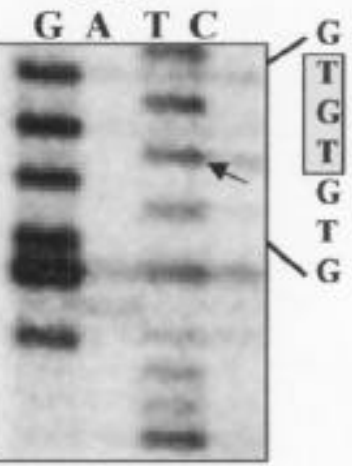

(c)

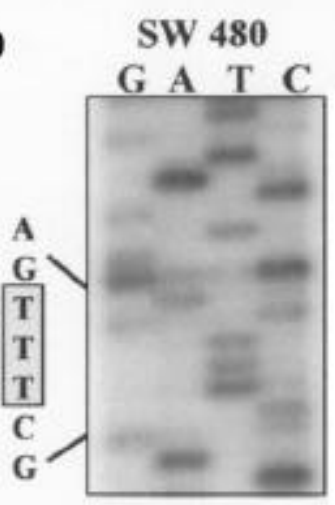

\section{G 33}

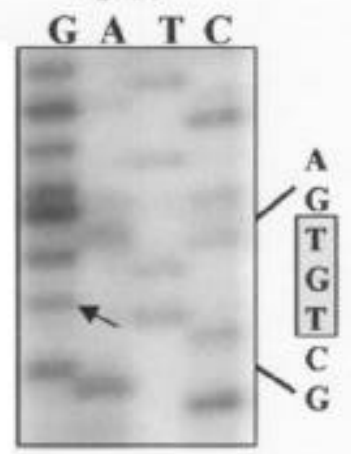

Figure 2. DNA sequence analysis of abnormal bands for selected samples. (a) Patient G2 has a missense mutation $(\mathrm{G}-\mathrm{T})$ in exon 5. (b) Patient G23 has a missense mutation (C-T). (c) Patient G33 has a missense mutation (T-G). The DNA sequence of control sample (left) and the patient (right) are shown. Total DNA from SW480 cells was used as control sample. Normal and mutated codons are boxed and shaded. The cell line SW480 carries a mutation in exon 8 at codon 273 due a missense mutation $(\mathrm{G}-\mathrm{A})$, which results in the conversion of normal codon CGT to CAT. viously by others. Mutations of p53 were detected both in low-grade (grade II) and high-grade (grade III, IV) gliomas, with frequencies varying between 25 and 35\% (Ohgaki et al 1995). Our results show that the p53 mutation frequency is higher in low-grade gliomas than in high-grade gliomas. Grade II gliomas, which mainly comprise astrocytomas, had a frequency of $25 \%$ (3/12), while grade III gliomas, which are mainly anaplastic astrocytomas, had a frequency of $15.4 \%(2 / 13)$. In contrast to this, the p53 mutation occurred at a low frequency of $5.4 \%(1 / 19)$ among grade IV glioblastoma multiforme cases. Three of the six p53 mutations were found in grade II gliomas.

Other mechanisms implicated in the abnormal functioning of p53 are the amplification of MDM2 gene and the inactivation of $p 14^{A R F}$ gene product. The binding of MDM2 protein to p53 results not only in the inhibition of p53-mediated transcription, but also in the rapid degradation of p53 (Oliner et al 1993; Haupt et al 1997; Kubbutat et al 1997). The binding of $\mathrm{p} 14^{\mathrm{ARF}}$ to the MDM2 protein inhibits the MDM2-mediated degradation of p53 (Kamijo et al 1998; Stott et al 1998; Zhang et al 1998; Orlow et al 1999). Studies of the status of MDM2 and $p 14^{A R F}$ genes in these glioma samples are currently in progress.

\section{Acknowledgements}

This study was supported by a grant from Sir Dorabji Tata Centre for Research in Tropical Diseases (SDTC), Indian Institute of Science, Bangalore.

\section{References}

Bigner S H, Mark J, Burger P C, Mahaley M S, Bullard D E, Muhlbaier L H and Bigner D 1988 Specific chromosomal abnormalities in malignant human gliomas; Cancer Res. 88 405-411

Burger P C and Scheithauer B W 1993 Tumors of the central nervous system (Washington DC: Armed Forces Institute of Pathology)

Chattopadhyay P, Rathore A, Mathur M, Sarkar C, Mahapatra A K and Sinha S 1997 Loss of heterozygosity of a locus on $17 \mathrm{p} 13.3$, independent of $\mathrm{p} 53$, is associated with higher grades of astrocytic tumours; Oncogene 15 871-874

Chung R, Whaley J, Kley N, Anderson K, Louis D, Meneon A, Hettlich C, Freiman R, Hedley-White E T, Marutza R, Jenkins R, Yandell D and Seizinger B 1991 TP53 gene mutations and $17 \mathrm{p}$ deletion in human astrocytomas; Genes Chromosomes Cancer 3 323-331

Epstein F and McCleary E L 1986 Intrinsic brain-stem tumors of childhood: surgical indications; J. Neurosurg. 64 11-15

Frankel R H, Bayona W, Koslow M and Newcomb E W 1992 p53 mutations in human malignant gliomas: comparison of loss of heterozygosity with mutation frequency; Cancer Res. 52 1427-1433

Fujimoto M, Fluts D W, Thomas G A, Nakamura Y, Heilbrun M P, White R, Story J L, Naylor S L, Kagan-Hallet K S and 
Sheridan P J 1989 Loss of heterozygosity on chromosome 10 in human glioblastoma multiforme; Genomics 4 210-214

Fults D, Brockmeyer D, Tullous M W, Pedone C A and Cawthon R M 1992 p53 mutations and loss of heterozygosity on chromosomes 17 and 10 during human astrocytoma progression; Cancer Res. 52 674-679

Ghosh M, Dinda A, Chattopadhyay P, Sarkar C, Bhatia S and Sinha S 1994 Rearrangement of p53 gene with loss of normal allele in a low grade non recurrent mixed glioma; Cancer Genet. Cytogenet. 78 68-71

Haupt Y R, Maya R, Kaza A and Oren M 1997 Mdm2 promotes the rapid degradation of p53; Nature (London) 387 296-297

Hollstein M, Sidransky D, Vogelstein B and Harris C C 1991 p53 Mutations in human cancers; Science 253 49-53

Jain K C, Chattopadhyay P, Sarkar C, Sinha S and Mahapatra A K 1999 A pilot study of recurrence of human glial tumours in light of p53 heterozygosity status; J. Biosci. 24 477-481

James C D, Carlbom E, Dumanski J P, Hansen M, Nordenskjold M, Collins V P and Cavenee W K 1988 Clonal genomic alteration in glioma malignancy stages; Cancer Res. 48 5546-5551

Kamijo T, Weber J D, Zambetti G, Zindy F, Roussel M F and Sherr C J 1998 Functional and physical interactions of the ARF tumor suppressor with $\mathrm{p} 53$ and $\mathrm{Mdm} 2$; Proc. Natl. Acad. Sci. USA 95 8292-8297

Kovach J S, McGovern R M, Cassady J D, Swanson S K, Wold L S, Vogelstein B and Sommer S S 1991 Direct sequencing from touch preparations of Human carcinomas: Analysis of p53 mutations in Breast carcinoma; J. Natl. Cancer Inst. 83 1004-1009

Kubbutat M H G, Jones S N and Vousden K 1997 Regulation of p53 stability by MDM2; Nature (London) 387 299-303

Levine A J 1997 p53, The cellular gatekeeper for growth and division; Cell 88 323-331

Levine A J, Momand J and Finlay C A 1991 The p53 tumor suppressor gene; Nature (London) 351 453-456

Libermann T A, Nusbaum H R, Razon N, Kris R, Lax I, Soreq $\mathrm{H}$, Whittle N, Waterfield M D, Ullrich A and Schlessinger J 1985 Amplification, enhanced expression and possible rearrangement of the EGF receptor gene in primary human brain tumors of glial origin; Nature (London) 313 144-147

Louis D N, von Deimling A, Chung R Y, Rubio M-P, Whaley J M, Eibl R H, Ohgaki H, Weistler O D, Thor A D and Seizinger B R 1993 Comparative study of p53 gene and protein alterations in human astrocytic tumors; J. Neuropathol. Exp. Neuro. 52 31-38

Mashiyama S, Murakami Y, Yoshimoto T, Sekiya T and Haya- shi K 1991 Detection of p53 gene mutations in human brain tumors by single strand conformation polymorphism analysis of polymerase chain reaction product; Oncogene 6 13131318

Nigro J, Baker S J, Presisinger A C, Jessup J M, Hostetter R, Cleary K, Bigner S H, Davidson N, Baylin S, Devilee P, Glover T, Collins F S, Weston A, Modali R, Harris C C and Vogelstein B 1989 Mutations in the p53 gene occur in diverse human tumor types; Nature (London) 342 705-708

Ohgaki H, Eibl R H, Wiestler O D, Yasargil M G, Newcomb E W and Kleihues P 1991 p53 Mutations in nonastrocytic human brain tumors; Cancer Res. 51 6202-6205

Ohgaki H, Schauble B, zur Hausen A, von Ammom K and Klehues P 1995 Genetic alterations associated with the evolution and progression of astrocytic brain tumors; Virchows Arch. 427 113-118

Oliner J D, Pientenpol J A, Thiagalingam S, Gyuris J, Kinzler K W and Vogelstein B 1993 Oncoprotein MDM2 conceals the activation domain of tumor suppressor p53; Nature (London) $362857-860$

Orlow I, LaRue H, Osman I, Lacombe L, Moore L, Rabbani F, Meyer F, Fradet Y and Cordon-Cardo C 1999 Deletions of the INK4A gene in superficial bladder tumors. Association with recurrence; Am. J. Pathol. 155 105-113

Rasheed B K A, McLendon R E, Herndon J E, Friedman H S, Friedman A H, Bigner D D and Bigner S H 1994 Alterations of the TP53 gene in human gliomas; Cancer Res. 54 13241330

Saxena A, Clark W C, Robertson J T, Ikejiri B, Oldfield E H and Ali I U 1992 Evidence for the involvement of a potential second tumor suppressor gene on 17 distinct from p53 in malignant astrocytomas; Cancer Res. 52 6716-6721

Somasundaram K and El-Deiry W S 2000 Tumor suppressor p53: regulation and function; Frontiers Biosci. 5 d424-437

Stott F J, Bates S, James M C, McConnell B B, Starborg M, Brookes S, Palmero I, Ryan K, Hara E, Vousden K H and Peter G 1998 The alternative product from the human CDKN2A locus, p14 ${ }^{\mathrm{ARF}}$, participates in a regulatory feedback loop with p53 and MDM2; EMBO J. 17 5001-5014

von Deimling A, Eibl R H, Ohgaki H, Louis D N, von Ammon K, Petersen I, Kleihues P, Chung R Y, Wiestler O and Seizinger B R 1992 p53 mutations are associated with 17p allelic loss in grade II and grade III astrocytomas; Cancer Res. 52 2987-2990

Zhang Y, Xiong Y and Yarbrough W G 1998 ARF promotes MDM2 degradation and stabilizes p53: ARF-INK4a locus deletion impairs both the $\mathrm{Rb}$ and p53 tumor suppression pathways; Cell 92 725-734

\section{MS received 19 July 2002; accepted 22 October 2002}

Corresponding editor: PRAgna I PATEL 